\title{
Psychological evaluation by using the Hamilton depression and anxiety rating scales in coronary artery bypass grafting patients undergoing cardiovascular rehabilitation treatment
}

\author{
Razan Al Namat', Maura Felea', Amin Bazyani, ${ }^{3,4}$, Liviu Macovei ${ }^{3,4}$, Marius Adoamnei ${ }^{4}$, Dan Nastasa4, Nicusor \\ lovin ${ }^{4}$, lonut Achitei ${ }^{4}$, Paul Simion ${ }^{4}$, Nadia Al Namat ${ }^{3}$, Dina Al Namat ${ }^{3}$, Tamer Abu Amar ${ }^{3}$, Ana Tanasa ${ }^{3,4}$, Ovidiu \\ Mitu', Grigore Tinica ${ }^{3,4}$, Larisa Anghel ${ }^{3,4}$, Alexandru Burlacu ${ }^{3,4}$, Florin Mitu'
}

\begin{abstract}
Cardiovascular disease is one of the leading causes of morbid-mortality, although better outcomes and lower mortality of age-adjusted coronary artery disease were registered since 1980s, especially in high-income populations, sustaining the cost-effective of cardiac prevention methods. The aim of this prospective study was to evaluate the role of cardiac rehabilitation in improving psycho-emotional risk scores: the Hamilton Depression (HAM-D) and Anxiety Rating Scale (HAM-A) in coronary artery bypass grafting (CABG) patients, in less than one week after cardiovascular surgery and in 6 months follow-up after the engagement in the cardiac recovery program. Methods - During 01.05.2015-01.03.2017, CABG was performed in 100 patients, aged 40-80 years old, who followed rehabilitation in the Cardiovascular Rehabilitation Clinic. The mean age of the patients under study was $65.70 \pm 9.91$ years old. Results - In the first phase of the cardiovascular rehabilitation program, the mean values were: 16 points for HAM-D, and 25 points on HAM-A scale. By comparing the Phase I and Phase III results, the median HAM-D score improved more than 50\%, and HAM-A about 36\% $(p<0.05)$. Conclusion - The study highlighted the role of early rehabilitation after CABG surgery and the HAM-D and HAM-A scores improvement, emphasizing the importance of including psycho-emotional status assessment in the management of the patient who benefited from cardiac surgery. Apart from clinical data and the cardiovascular risk scores, the psycho-emotional risk stratification can provide important information regarding outcomes and prognosis.
\end{abstract}

Keywords: coronary disease, CABG, HAM-D scale, HAM-A scale, cardiovascular recovery.

Rezumat: Boala cardiovasculară este principala cauză de mortalitate și morbiditate. În ultimii ani s-a obsevat o ameliorare a rezultatelor, prin scăderea numărului deceselor de cauză cardiovasculară. De altfel, acest lucru s-a produs începând cu anii 1980, în special în țările cu un nivel de trai ridicat, în programe de recuperare cardiovasculară. Scopul acestui studiu prospectiv a fost de a evalua rolul reabilitării cardiace în îmbunătățirea scorurilor de risc psiho-emoțional: scorul de depresie Hamilton (HAM-D) și scala de evaluare a anxietății (HAM-A) în cazul pacienților cu by-pass aorto-coronarian (CABG) la mai puțin de o săptămână după CABG și după 6 luni de urmărire într-un program de recuperare cardiovasculară. Material și metodă - În perioada 01.05.2015 - 01.03.2017 s-a efectuat CABG la 100 de pacienți, cu vârsta cuprinsă între 40-80 de ani,

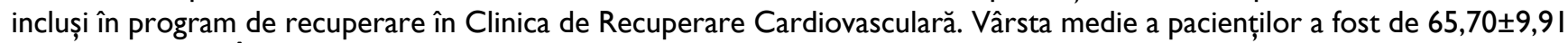
ani. Rezultate - În prima fază a programului de recuperare cardiovasculară, valorile medii au fost: 16 puncte pentru HAMD și 25 de puncte pentru scara HAM-A. Prin compararea rezultatelor de fază I și de fază III, scorul median al HAM-D s-a îmbunătățit cu mai mult de 50\% și HAM-A cu aproximativ $36 \%(p<0,05)$. Concluzii - Studiul a evidențiat rolul recuperării cardiovasculare după CABG și îmbunătățirea scorurilor HAM-D și HAM-A, subliniind importanța includerii evaluării statusului psiho-emoțional în gestionarea pacientului care a beneficiat de CABG. În afara datelor clinice și a scorurilor de risc cardiovascular, stratificarea riscului psiho-emoțional poate furniza informații importante cu privire la rezultate și prognostic. Cuvinte cheie: boală coronariană, CABG, scară HAM-D, scară HAM-A, recuperare cardiovasculară.

\footnotetext{
' Ist Medical Department, Faculty of Medicine, „Grigore T. Popa” University of Medicine and Pharmacy, lasi, Romania

$23^{\text {rd }}$ Medical Department, Faculty of Medicine, „Grigore T. Popa” University of Medicine and Pharmacy, lasi, Romania

${ }^{3}$ „Grigore T. Popa” University of Medicine and Pharmacy, lasi, Romania

${ }^{4}$ Institute for Cardiovascular Diseases, lasi, Romania
}

\section{Contact address:}

Maura Felea, I ${ }^{\text {st }}$ Medical Department, Faculty of Medicine, „Grigore T. Popa" University of Medicine and Pharmacy, 16 Universitatii Street, 700II5, lasi, Romania.

E-mail: feleamag@yahoo.com 


\section{INTRODUCTION}

The European Guidelines on Cardiovascular Prevention from 2016, developed by ten European societies, promote the prevention of cardiovascular diseases as a coordinated set of population-based or individual-directed actions, targeting to cancel or to minimize the impact of cardiovascular diseases (CVD) and associated deficiencies on patients and their family caregivers, on physicians, as well as on the social system, health care and health insurance system'. Applying preventive measures and anti-smoking legislation, it reduced to more than $50 \%$ the CVD rates in the last 40 years in most European countries; inequalities are due particularly to increased frequency of obesity and diabetes mellitus $(D M)^{2}$. A common symptom post-CABG surgery is depression, linked with the worse clinical outcomes, unceasing chest pain, poor functional status and health-related quality of life (HRQoL), frequent hospitalization and high mortality rate ${ }^{2}$.

The Hamilton Depression Rating Scale (HRSD), also called the Hamilton Rating Scale for Depression (HAM$D)$, is a multiple item inventory, used as a tool in psychiatric evaluation of depression as well as an index in evaluating recovery progress. Max Hamilton originally published the scale in 1960, but he reviewed it many times ${ }^{3}$. The questionnaire, designed for adults, was performed to assess the severity of low mood, depression, insomnia, the degree of anxiety in patients already diagnosed as suffering from neurotic anxiety states, fears, and, among the somatic symptoms, there were the cardiovascular and respiratory ones ${ }^{4}$. The Hamilton Anxiety Rating Scale (HAM-A), among the first scales, was designed to measure the severity of anxiety symptoms, and it is widely used in psychiatry as well as in other specialties, for clinical and research purposes $^{5}$. The 14 aspects of the scale include symptoms that measure psychic anxiety and somatic anxiety, thus describing mental agitation, psychological stress and the relation between physical symptoms and anxiety ${ }^{6}$.

By this study, we aimed to evaluate the benefits of the cardiovascular rehabilitation program upon the Hamilton Depression and Anxiety Scales scores in patients who underwent $C A B G$ surgery. The score values were determined during the first phase (first week after cardiac surgery) and the third phase of cardiovascular rehabilitation period, six months later.

\section{MATERIAL AND METHODS}

We conducted a prospective study among patients admitted in the Clinic of Cardiovascular Surgery of the
Institute of Cardiovascular Disease of lasi. Rehabilitation program includes three phases: the first is the Ist week immediately after surgery, the second is after three months, and the last is performed at six months. The inclusion criteria: only CABG patients (less than I week after surgery); age between $40-80$ years old; cardio-metabolic condition; left ventricular ejection fraction $<50 \%$. Exclusion criteria: mental illness, physical disability, lack of cooperation and cancer.

During 0I.05.20I5-01.03.20I7, 100 patients met the inclusion criteria, thus benefiting from cardiovascular rehabilitation program, including physical exercise, in the Cardiovascular Rehabilitation Clinic of the Rehabilitation Hospital of lasi. The study had the approval of the University Ethics Committee, all participants in the study signing an informed consent.

\section{STATISTICAL ANALYSIS}

Anthropometric, social, clinical, laboratory, and scores data were collected using Microsoft Office Excel 2010 version. Statistical analysis was done in IBM SPSS Statistics v.20, using it to calculate the average, frequency, and standard deviations for the variables, differences between the maximum and minimum values of the numerical parameters.

\section{RESULTS}

The mean age of the patients under study was 65.70 \pm 9.91 years old, with an average age of $65.26 \pm 10.26$ for men, and $66.96 \pm 8.89$ respectively for female patients, subjects ranging in age between $40-80$ years old. Most individuals in the group were overweight or obese, having a body mass index (BMI) $>25 \mathrm{~kg} / \mathrm{m}^{2}$, confirming the upward trend of obesity at national and global levels. The appearance of changes recorded on the electrocardiogram (ECG) revealed the presence of atrial fibrillation in phase I in 66 patients, but in the $3^{\text {rd }}$ phase of the cardiovascular rehabilitation program only $9 \%$ of patients showed this rhythm disorder.

The scores of HAM-D questionnaire: normal mood (0-7 points), mild depression (8-13 points), moderate depression (14-18 points), severe depression (19-22 points), and very severe depression ( $\geq 23$ points). The Hamilton of Anxiety Rating Scale (HAM-A) consisted of 14 elements, anxiety levels are: mild anxiety $(\leq 17)$, mild to moderate severity (18-24 points), moderate to severe anxiety (25-30 points), and very severe ( $\geq 31$ points) ${ }^{7}$.

By using our 100 patients who benefited from enrollment into the cardiovascular rehabilitation pro- 
gram, the descriptive statistics estimates the level of depression and anxiety immediately after cardiac surgery and later on, after 6 months, thus highlighting the importance of the program in ameliorating the mental and emotional mood of the patients (Table I).

Thus, in the first week after CABG, $50 \%$ of the patients had moderate and severe depression, while 6 months later, $50 \%$ of the total group had amelioration to mild depression status and normal mood. Comparing the Phase I and Phase III results, it is noted that the HAM-D median value has been reduced by $56.17 \%$, reflecting the benefit of the rehabilitation program in improving post-interventional depression $(p<0.05)$ (Figure I).

Comparing the Phase I and Phase III results, it is noticed that the HAM-A median value was approximately $9 \%$ lower, reflecting the benefit of the rehabilitation program in improving post-interventional anxiety $(p<0.05)$ (Figure 2).

For each case, on SPSS program, we calculated the difference between first phase values (score_0) and the last phase values (score_I). Ties (cases whose two values are equal) were absent, this explaining that, for every patient, both HAM-D and HAM-A had positive amelioration and all patients presented a favorable change in mood status (Table 2).

By computing the test statistic Wilcoxon $\mathrm{W}+$, whi$\mathrm{ch}$ is the sum over positive signed ranks, we found out, for both HAM-D and HAM-A, that the scores in both phases have similar population distributions, with a $W+$ which was neither very small nor very large (Table 3). As a remark, in our group, the decrease of depression and anxiety scores are also similar in maximal absolute value.

\section{DISCUSSIONS}

In the study, which included 100 patients with aortic coronary bypass surgery, we analyzed the link between low levels of post-surgical general health status and the presence of cardiovascular risk factors, common biochemical markers, and the role of recovery therapy in the improvement of postoperative psycho-emotional symptoms, especially depression and anxiety.

The Hamilton Rating Scale for Depression (HRSD), abridged as HAM-D, is a multiple-item questionnaire that can provide an index of depression, useful as a guide in evaluating recovery and not as a diagnostic tool, as Hamilton pointed out ${ }^{8,9}$. Comparing the Phase I and Phase III results, we noticed an almost $50 \%$ reduction of the median HAM-D score, reflecting the benefit of the recovery program in improving depression after cardiac surgery $(p<0.05)$.

HAM-A was one of the first assessment scales developed to measure the severity of anxiety symptoms, and although HAM-A remains widely used in clinical trials, it was criticized for failing to distinguish betwe-

\begin{tabular}{|l|c|c|c|c|c|}
\hline Table I. Comparative HAM-D and HAM-A values between rehabilitation phases & Minimum & Maximum \\
\hline & N & Mean & 2.189 & $1 \mathrm{I}$ & 22 \\
\hline Ham Depress Score_T0 & 100 & 15.88 & $3.54 \mathrm{I}$ & 18 & 30 \\
\hline Ham Anx Score_T0 & 100 & 25.13 & 2.696 & 2 & 12 \\
\hline Ham Depress Score_TI & 100 & 6.96 & 1.442 & 14 & 19 \\
\hline Ham Anx Score_TI & 100 & 15.68 & & 19 \\
\hline
\end{tabular}

\begin{tabular}{|c|c|c|c|c|}
\hline & & $\mathbf{N}$ & Mean Rank & Sum of Ranks \\
\hline \multirow{4}{*}{$\begin{array}{l}\text { HAM-Depress Score_TI - } \\
\text { HAM-Depress Score_TO }\end{array}$} & Negative Ranks & $100^{a}$ & 50.50 & 5050.00 \\
\hline & Positive Ranks & $0^{\mathrm{b}}$ & .00 & .00 \\
\hline & Ties & $0^{c}$ & & \\
\hline & Total & 100 & & \\
\hline \multirow{4}{*}{$\begin{array}{l}\text { HAM-Anx Score_TI - } \\
\text { HAM-Anx Score_TO }\end{array}$} & Negative Ranks & $100^{d}$ & 50.50 & 5050.00 \\
\hline & Positive Ranks & $0^{\mathrm{e}}$ & .00 & .00 \\
\hline & Ties & $0^{f}$ & & \\
\hline & Total & 100 & & \\
\hline \multicolumn{5}{|c|}{$\begin{array}{l}\text { a. HAM-D Score_TI < HAM-D Score_T0; b. HAM-D Score_TI > HAM-D Score_T0; } \\
\text { c. HAM-D Score_TI = HAM-D Score_T0 }\end{array}$} \\
\hline \multicolumn{5}{|c|}{$\begin{array}{l}\text { d. HAM-A Score_TI < HAM-A Score_T0; e. HAM-A Score_TI > HAM-A Score_T0; } \\
\text { f. HAM-A Score_TI = HAM-A Score_T0 }\end{array}$} \\
\hline
\end{tabular}




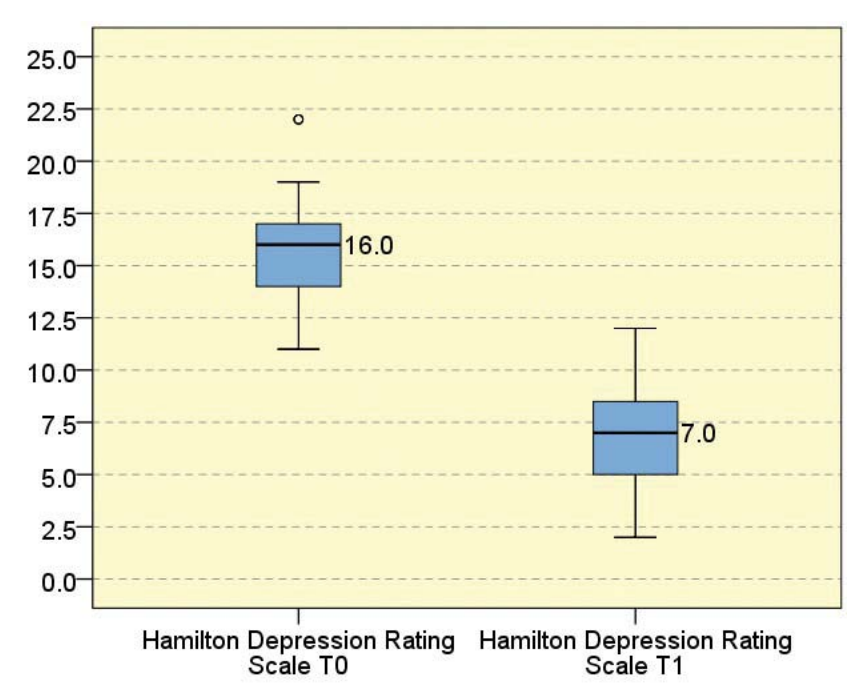

Figure I. Descriptive statistics of HAM-D score in phase I and III.

\begin{tabular}{|l|c|c|}
\hline \multicolumn{3}{|l|}{ Table 3. Test Statistics } \\
\hline & $\begin{array}{c}\text { HAM-D Score_TI } \\
\text { - HAM-D Score_TO }\end{array}$ & $\begin{array}{c}\text { HAM-A Score_TI } \\
\text { - HAM-A Score_TO }\end{array}$ \\
\hline$Z$ & $-8.718^{\mathrm{b}}$ & $-8.702^{\mathrm{b}}$ \\
\hline $\begin{array}{l}\text { Asymp. Sig. } \\
\text { (2-tailed) }\end{array}$ & .000 & .000 \\
\hline \multicolumn{2}{|l|}{ a. Wilcoxon Signed Ranks Test; b. Based on positive ranks } \\
\hline
\end{tabular}

en anxiolytic and antidepressant effects, and between somatic anxiety versus somatic side effects ${ }^{10,11}$. By comparing the Phase I and Phase III results, it is noted that the HAM-A median was approximately $9 \%$ lower, reflecting the benefit of the recovery program in improving post-interventional status of anxiety $(p<0.05)$.

Between phase I and phase III of the cardiovascular rehabilitation program, representing a period of six months, 57 out of 66 patients with atrial fibrillation (86.36\%) converted to sinus rhythm, also the echocardiographic parameters regarding showed an improvement. Lipid profile values showed a statistically significant decrease. The complex cardiovascular rehabilitation program includes cycloergometer testing, both immediately after myocardial infarction surgery, and in the first phase of rehabilitation to assess patients' exercise capacity with beneficial effects upon increasing physical exercise capacity, walking perimeter, and improving the quality of life.

In Phase I (one week after myocardial infarction), the physical capacity of the patients was limited; $55 \%$ of patients were able to achieve only a minimal effort of IMETs, $35 \%$ of them were capable of an effort of 2 METs, and $10 \%$ could perform an effort of 3 METs.

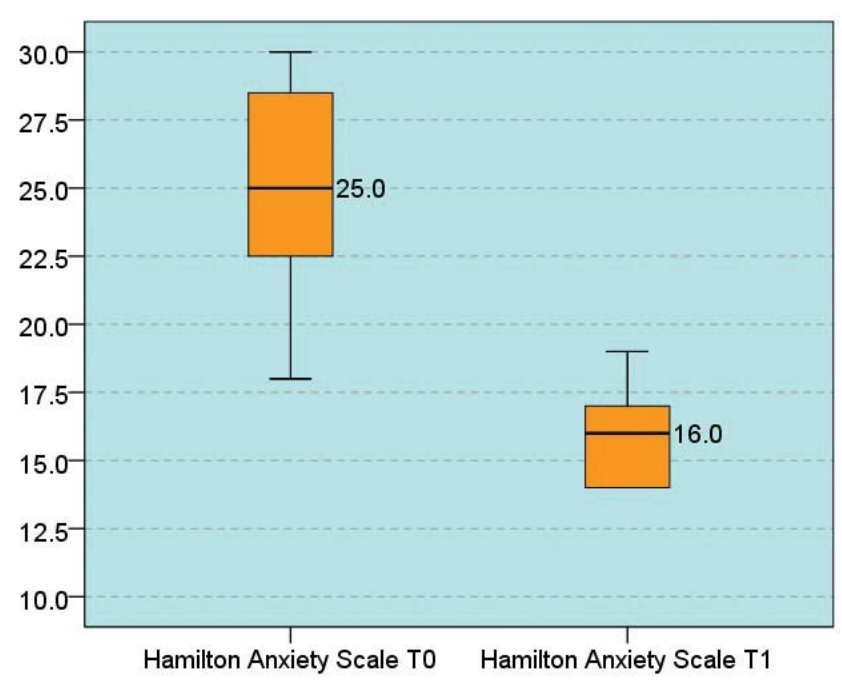

Figure 2. Descriptive statistics of HAM-A score in phase I and III.

In this phase, no one had been able to make an effort better than 3 METs.

In the third phase of cardiovascular rehabilitation, all patients, that initially have been achieving a minimum effort of I-3 METs, have improved this time, and even exceeded, their poor physical condition by performing average efforts classified in the 4-5 METs group, with nearly $2 / 3$ of patients in class 5 METs.

The effects of the cardiac rehabilitation program in patients after cardiac surgery were seen in decreasing complications and improving QoL. Although there are specific recommendations after CABG surgery, there is a very low enrollment in the cardiac rehabilitation programs. In some countries, healthcare providers turned to home-based cardiac rehabilitation program instead of center-based care ${ }^{12}$.

According to the main Italian and international guidelines on mood disorders diagnosis in cardiac patients , eight principal instruments can be used: the Hospital Anxiety and Depression Scale (HADS), the Cognitive Behavioural Assessment Hospital Form (CBA-H), the Beck Depression Inventory (BDI), the two and nine-item Patient Health Questionnaire (PHQ-2, PHQ-9), the Depression Interview and Structured Hamilton (DISH), the Hamilton Rating Scale for Depression (HAM-D/HRSD), and the Composite International Diagnostic Interview (CIDI) ${ }^{13}$.

The combined effects of depression and anxiety symptoms in CABG patients could be found only in three case studies. They have been done in order to assess the importance of mood disorders- their importance and recovery. Findings were mixed. The first study of 193 patients presented pre-surgical depressi- 
on symptoms, but not anxiety. Six months follow up after surgery, poor life quality was found (as predicted before surgery) $)^{14,15}$. The second study case included 158 CABG patients. They presented generalized anxiety, but not major depression and predicted major adverse cardiovascular and cerebrovascular events ${ }^{16}$. The third study group had post-operative anxiety, but no depression symptoms, in order to predict major adverse events and mortality up to four years after surgery in a sample of 180 CABG patients. It is not yet clear, therefore, to what extent anxiety symptoms can predict cardiac morbidity and mortality over and above depression symptoms or the reverse ${ }^{17}$.

\section{CONCLUSIONS}

The study highlighted the role of early rehabilitation after CABG surgery revealed by the symptoms relief, the HAM-D and HAM-A scores improvement, and the echocardiography data changes, emphasizing the importance of including psycho-emotional status assessment in the complex management of the patient who benefited from cardiac surgery. Psycho-emotional risk (HAM-D and HAM-A) stratification can provide further important information apart from clinical data, regarding outcomes and prognosis. After a thorough research into major international databases, this study is probably the first to attempt an evaluation of the relationship between HAM-D and HAM-A; it also presents the cardiovascular recovery outcomes post-coronary artery bypass.

\section{Conflict of interest: none declared.}

\section{References}

I. Piepoli MF, Hoes AW, Agewall S, Albus C, Brotons C, Catapano AL, Cooney MT, Corrà U, Cosyns B, Deaton C, Graham I, Hall MS, Hobbs FDR, Løchen ML, Löllgen H, Marques-Vidal P, Perk J, Prescott E, Redon J, Richter DJ, Sattar N, Smulders Y, Tiberi M, van der Worp HB, van Dis I, Verschuren WMM, Binno S. \& on behalf of the Task Force for the 2016 guidelines on cardiovascular disease prevention in clinical practice. Main messages for primary care from the 2016 European Guidelines on cardiovascular disease prevention in clinical practice. European Journal of General Practice 2017; 24(I): 5I-56.

2. Moran AE, Forouzanfar MH, Roth GA, Mensah GA, Ezzati M, Murray $C$, Naghavi $M$. Temporal trends in ischemic heart disease mortality in 21 world regions, 1980 to 2010: the Global Burden of Disease 2010 study. Circulation 2014; I29: |483-1492.
3. Hamilton M. Development of a rating scale for primary depressive illness. British Journal of Social and Clinical Psychology 1967; 6: 27896.

4. Hamilton $\mathrm{M}$. The assessment of anxiety states by rating. $\mathrm{Br} \mathrm{J}$ Med Psychol 1959; 32: 50-55.

5. Ceccarini M, Manzoni GM, Castelnuovo G. Assessing depression in cardiac patients: what measures should be considered?. Depress Res Treat. 20|4;ID: I 48256: I- 17.

6. Liang SY, Li XP. Recognition of depression/anxiety-complicated coronary diseases and evaluation of commonly used scales. J Translat Intern Med 20I4; I: 26-3I.

7. Poole L, Leigh E, Kidd T, Ronaldson A, Jahangiri M, Steptoe A. The combined association of depression and socioeconomic status with length of post-operative hospital stay following coronary artery bypass graft surgery: Data from a prospective cohort study. Journal of Psychosomatic Research 2014; 76: 34-40.

8. Siu AL, Bibbins-Domingo K, Grossman DC, Baumann LC, Davidson KW, Ebell M, García FA, Gillman M, Herzstein J, Kemper AR, Krist AH, Kurth AE, Owens DK, Phillips WR, Phipps MG, Pignone MP. Screening for depression in adults: US preventive services task force recommendation statement. JAMA 2016; 315: 380-387.

9. Stenman M, Holzmann MJ, Sartipy U. Relation of major depression to survival after coronary artery bypass grafting. The American Journal of Cardiology 2014; II4, 698-703.

10. Phillip JT, Helen RW, Robert AB, Johan D, Susanne SP, Gary AW, Deborah A. Turnbull. Depression, anxiety and major adverse cardiovascular and cerebrovascular events in patients following coronary artery bypass graft surgery: A five year longitudinal cohort study. BioPsychoSocial Medicine 2015; 9; 14.

II. Tyrer P, Cooper S, Salkovskis P, Tyrer H, Crawford M, Byford S, Dupont S, Finnis S, Green J, McLaren E, Murphy D, Reid S, Smith G, Wang D, Warwick H, Petkova H, Barrett B. Clinical and cost-effectiveness of cognitive behaviour therapy for health anxiety in medical patients: A multicentre randomised controlled trial. Lancet (London, England) 2014; 383, 219-225.

12. Kotseva K, Wood D, De Bacquer D, De Backer G, Rydén L, Jennings C, Gyberg V, Amouyel P, Bruthans J, Castro Conde A, Cífková R, Deckers JW, De Sutter J, Dilic M, Dolzhenko M, Erglis A, Fras Z, Gaita D, Gotcheva N, Goudevenos J, Heuschmann P, Laucevicius A, Lehto S, Lovic D, Miličić D, Moore D, Nicolaides E, Oganov R, Pajak A, Pogosova N, Reiner Z, Stagmo M, Störk S, Tokgözoglu L, Vulic D. EUROASPIRE IV: a European Society of Cardiology survey on the lifestyle, risk factor and therapeutic management of coronary patients from 24 European countries. Eur J Prev Cardiol 2016; 23: 636-648.

13. Tindle H, Belnap BH, Houck PR, Mazumdar S, Scheier MF, Matthews KA, He F, Rollman BL. Optimism, Response to Treatment of Depression, and Rehospitalization after Coronary Artery Bypass Graft Surgery. Psychosom Med 2012; 74(2): 200-207.

14. Nashef SA, Roques F, Michel P, Gauducheau E, Lemeshow S, Salamon R. European system for cardiac operative risk evaluation (euroscore). Eur. J. Cardio-Thorac. Surg 1999; 16: 9-13.

15. Rose M, Devine J. Assessment of patient-reported symptoms of anxiety. Dialogues in Clinical Neuroscience 2014; 16(2): 197-2II.

16. Gogas KR, Lechner SM, Markison S. Anxiety. Comprehensive Medicinal Chemistry II, 2007. Edition Elsevier Ltd. ISBN (Volume 6) 0-08-044519-5; pp. 85-II5.

17. Steptoe A, Poole L, Ronaldson A, Kidd T, Leigh E, Jahangiri M. Depression I year after CABG is predicted by acute inflammatory responses. Journal of the American College of Cardiology 2015; 65: $|7| 0-17 \mid 1$. 